\title{
Experimental Determination of Sound Transmission Loss of Some Wood Species
}

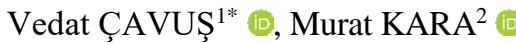 \\ ${ }^{1}$ Izmir Katip Celebi University, Forest Industry Engineering, İzmir, TURKEY \\ ${ }^{2}$ Abant Izzet Baysal University, Faculty of Engineering and Architecture, \\ Department of Mechanical Engineering, Bolu, TURKEY \\ *Corresponding Author: vedat.cavus@ikc.edu.tr
}

Received Date: 22.04 .2020

Accepted Date: 31.08 .2020

\begin{abstract}
Aim of study: To determine the sound transmission losses of 16 different wood species with the different density in the range of $100-1000 \mathrm{~Hz}$ frequencies, and the relationship between density and transmission loss was.

Material and methods: In this study sound transmission loss values of Ash (Fraxinus excelsior), Acacia (Robinia pseudoacacia L.), Beech (Betula pendula), Black pine (Pinus nigra), Black poplar (Populus nigra), Canadian poplar (Populus x euramaricana), Chestnut (Castanea sativa Mill.), Cypress (Cupressus sempervirens), Oriental beech (Fagus orientalis Lips,) Eucalyptus C. (E, camaldulensis Dehnh), Eucalyptus G. (Eucalyptus grandis), Juniper (Juniperus excelsa), Plane (Platanus orientalis L.), Scotch pine (Pinus sylvetris L), Turkish Red pine (Pinus brutia Ten) and White Oak (Quercus alba) wood specimens were determined by using the impedance tube kit.

Main results: Sound transmission loss is observed in lower density wood material species with the increasing frequency. However, a clear relationship has not been established between the mean sound transmission loss and density.

Highlights: It is important to determine the frequency-related acoustic performance parameters of the wood material and to its relationship with density.
\end{abstract}

Keywords: Acoustic Properties, Sound Transmission Loss, Wood Materials, Density

\section{Bazı Ağaç Türlerinin Ses İletim Kaybının Deneysel Olarak Belirlenmesi}

Öz

Çalışmanın amacl: farklı yoğunluğa sahip 16 farklı ağaç türünün 100-1000 Hz frekans aralığında ses iletim kaybı değerleri ile yoğunluk arasındaki ilişkinin belirlemektir.

Materyal ve yöntem: $\mathrm{Bu}$ çalı̧̧mada Dişbudak (Fraxinus excelsior), Akasya (Robinia pseudoacacia L.), Huş (Betula pendula), Karaçam (Pinus nigra), Kara kavak (Populus nigra), Kanada kavağı (Populus $x$ euramaricana), Kestane (Castanea sativa) Mill.), Selvi (Cupressus sempervirens), Doğu kayını (Fagus orientalis Lips,) Okaliptüs C. (Eucalyptus camaldulensis Dehnh), Okaliptüs G. (Eucalyptus grandis), Ardıç (Juniperus excelsa), Doğu Çınarı (Platanus orientalis L.), Sarıçam (Pinus sylvetris L), Türk Kızılçamı (Pinus brutia Ten.) ve Beyaz Meşe (Quercus alba) odunlarının ses iletim kaybı değerleri empedans tüp düzeneğinde belirlenmiştir.

Temel sonuçlar: Frekans arttığında, daha düşük yoğunluğa sahip ağaç malzeme türlerinde yüksek ses iletim kaybı gözlendiğini belirlenmiştir. Ancak, ortalama ses iletim kaybı ile yoğunluk arasında net bir ilişki belirlenmemiştir.

Araştırma vurguları: ağaç malzemenin frekansa bağlı akustik performans parametrelerinin belirlenmesi ve yoğunluk ile ilişkisinin tespit edilmesi önemlidir.

Anahtar Kelimeler: Akustik Özellikler, Ses İletim Kaybı, Ağaç Malzeme, Yoğunluk

\section{Introduction}

Wood materials are anisotropic, viscoelastic, polymeric and porous structures. They have low heat conductivity, low bulk density, easy machinability, high strength, good acoustic properties, material sustainability, low energy consumption and low carbon footprint etc. Wood is one of the most commonly used construction materials. Even more with the developing technology, 
one of the uses of it is in building systems (cross-laminated timber, glulam etc.) (Çavuş, 2019). Besides, it is preferred for making musical instruments as a structural and semistructural material. In general, wood material is known to have good acoustic properties. Despite there are many studies on the physical and mechanical properties of wood species in the literature but there is a slightly of data with the acoustic properties of wood and wood based products. Selection of wood species is made in accordance with the usage and purpose. Therefore, the properties of these materials must be determined accurately (Berkel, 1970; Voichita, 1995; Sirel, 2000; Selmani \& Sönmez, 2017; Bal \& Bektaş, 2018). Using wood materials in the decoration environment directly affects the acoustic behaviour (sound transmission or sound absorption). Therefore, it is very important to determine their acoustic behaviour, when properties of these types of decoration materials are considered.

Different parameters such as noise reduction coefficient, sound transmission loss or sound transmission class are used for examining the acoustic performance of materials in building acoustics (Crocker, 2007). In fact, these terms are parameters those can be calculated by determining the sound absorption coefficient or sound transmission coefficient. For example, the noise reduction coefficient is a value obtained by the average of the sound absorption coefficient at some certain frequencies. The sound absorption coefficient shows the capacity of sound energy absorption of a material, while the sound transmission coefficient shows the amount of transmitted sound power from one medium to another. Although these both terms affect the insulation performance of a medium from outer noise problems, generally, the transmission coefficient is measured for determining the insulation performance. On the contrary, sound absorption coefficient is a parameter used to regulate indoor acoustic comfort. Therefore, it is important to determine the sound absorption and transmission coefficient correctly.

The sound transmission and absorption coefficients are determined by experimental studies or empirical formulations. Empirical formulations are based on several assumptions; therefore they are applicable in certain frequency ranges. Therefore, the desired parameters are usually determined by experimental measurements. Experimental measurements can be performed via impedance tube (ASTM E1050, 2012; ASTM E2611-17, 2017) or conditioned acoustic laboratories such as reverberation rooms (ASTM C423-09, 2009), source-andreceiver rooms (ASTM E2249 - 19, 2003). Although realistic results are evaluated in reverberation rooms or source-and-receiver rooms, these laboratories have high initial investment costs. Thus impedance tube measurements are widespread among researchers.

In this study, frequency dependent sound transmission loss of different wood species, which are widely used as a construction material in furniture and decoration, structural and semi-structural applications, were determined in the impedance tube. The results were compared with each other and interpreted by considering the densities of the materials.

\section{Material and Methods \\ Material}

In this study, Ash (Fraxinus excelsior), Acacia (Robinia pseudoacacia L.), Beech (Betula pendula), Black pine (Pinus nigra), Black poplar (Populus nigra), Canadian poplar (Populus $x$ euramaricana), Chestnut (Castanea sativa Mill.), Cypress (Cupressus sempervirens), Oriental beech (Fagus orientalis Lips, $)$ Eucalyptus C. (E, camaldulensis Dehnh), Eucalyptus G. (Eucalyptus grandis), Juniper (Juniperus excelsa), Plane (Platanus orientalis L.), Scotch pine (Pinus sylvetris L), Turkish Red pine (Pinus brutia Ten) and White Oak (Quercus alba) are considered as test specimens. They are widely used as construction material in furniture and decoration, structural and semi-structural applications. The wood materials used in the production of test specimens were obtained from İzmir region in Turkey. According to the TS 2470 Standard (1976), the supplied wood materials were taken care that they were not knotted, smooth-bodied, without 
fibre curl, without reaction wood, not exposed to insect and fungal pests and especially from sapwood.

\section{Methods}

Prior to testing, the initial dimensions of wood planks were cut to 20x130x500 mm before they were dried and then they were conditioned at a relative humidity of $65 \pm 5 \%$ and temperature of $20 \pm 2{ }^{\circ} \mathrm{C}$ during 6 months until they became air dry. The moisture content of test specimens was approximately $12 \%$. The conditioned wood materials were first cut to $12 \times 120 \times 400 \mathrm{~mm}$ in the band saw machine and one side was planed and then they were brought to $10 \mathrm{~mm}$ thickness in the thickness machine. Both sides of the test specimens were passed through automatic wide-belt sanding/calibrating machine with first roller 80 and second roller 120 sand with a speed of $5 \mathrm{~m} \mathrm{/} \mathrm{min} \mathrm{in} \mathrm{order} \mathrm{to} \mathrm{get} \mathrm{the} \mathrm{same}$ thickness and smooth surface. The average last thickness value of the test specimens were $8 \mathrm{~mm}$. For the impedance tube experiments, the test specimens were cut to the desired size and precision with a speed of $8 \mathrm{~mm} / \mathrm{sec}$ using CNC laser-cutting machine. Automatic wide-belt sanding/ calibrating machine. CNC Laser Cutting Machine and test specimens are shown in Figure 1. The dimensions of all wood species test specimens for impedance tube test were 8 $\mathrm{mm}$ thickness and with the diameter $99 \mathrm{~mm}$.
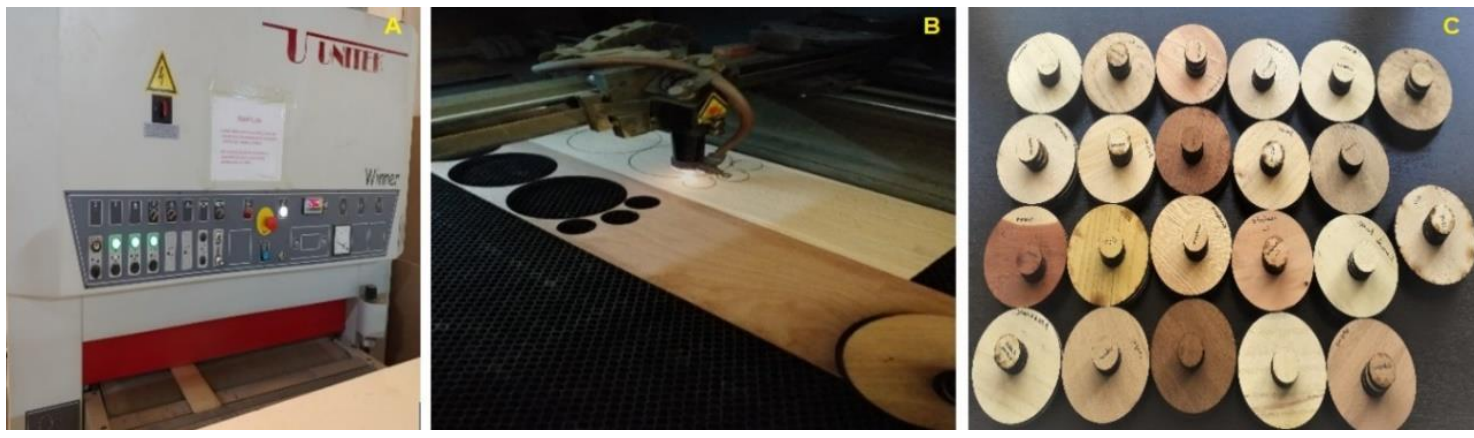

Figure 1. A) Automatic wide-belt sanding/calibrating machine, B) CNC Laser Cutting Machine, C) Test specimens.

Air-dry density values are determined according to TS 2472 standard (1976). The conditioned wood material was first cut 20x20x30 mm for determine air-dry density. The weights of the test specimens were weighed with $0.01 \mathrm{~g}$ precision analytical balance and the digital dial indicator clock with $\pm 0.0001 \mathrm{~mm}$ precision were used to evaluate their dimensions. The air-dry densities of the test samples were calculated using the following Eq. (1):

$\mathrm{D}_{12}=\frac{\mathrm{M}_{12}}{\mathrm{~V}_{12}}$

where $D_{12}$ is air-dry density $\left(\mathrm{gr} / \mathrm{cm}^{3}\right), M_{12}$ is air-dry weight (gr) and $V_{12}$ is air-dry volume $\left(\mathrm{cm}^{3}\right)$.

When the sound impinges to a panel/absorber, the panel absorbs the some part of the sound, some part of sound is reflected from the panel and remaining part of sound is transmitted through the panel. There are different measures of them. Sound transmission loss (TL) is a measure of the ratio of the incident sound power and transmitted sound power in terms of decibel. Although each material has different TL, similar tendency is observed in TL-frequency graph of each panel/material. Consider Figure 2 in order to express behaviour of a material (Bies \& Hansen, 2009). As it is observed from Figure 2, TL of a material decreases up to certain frequency, i.e., first resonance frequency of the panel. TL of a material up to first panel resonance frequency is dominated by the stiffness properties of the panel therefore this region is known as stiffness controlled region. After the first panel frequency, mass of the panel is dominant on TL and this frequency band is known as mass controlled region. In this region, TL is increases with frequency at the rate of $6 \mathrm{~dB}$ per octave (doubling frequency) 
which is known as mass law (Bies \& Hansen, 2009). Mass controlled region ends at the frequency at which bending wave speed of the material coincides with the speed of sound. Next, damping controlled region is observed in TL curves.

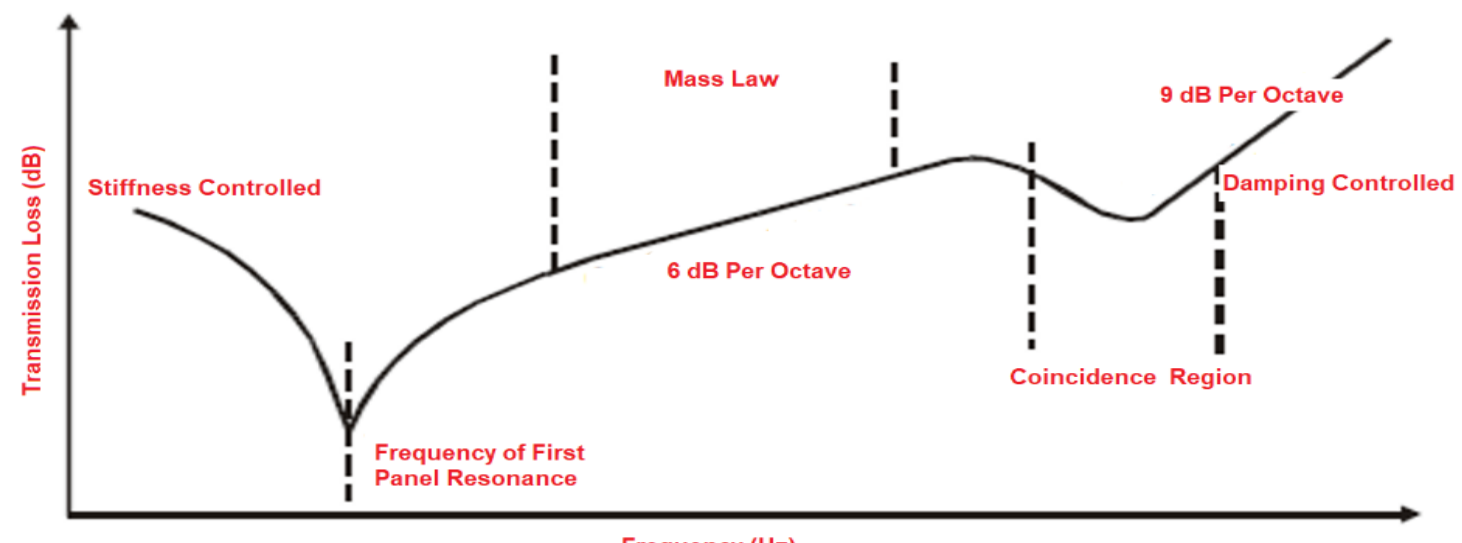

Frequency $(\mathrm{Hz})$

Figure 2. Sound transmission loss behaviour of an arbitrary material (Bies \& Hansen, 2009)

Transfer matrix method is a method to analyse the acoustic materials and mufflers. In this method any complex structure is divided to its simple components such as acoustic uniform pipe, sudden expansion or contraction, etc... Then, pressure and mass velocity relations between the ends of the simple component are expressed by $2 \times 2$ matrix. Multiplying the transfer matrices of connected simple components leads to evaluate the characteristics of acoustic muffler. However, for passive insulation materials and complex acoustical structures, analytical determination of transfer matrix elements is not an easy task. Therefore, experimental procedures i.e., two-load method (Lung \& Doige, 1983; ASTM E2611-17, 2017) and two-source method (Munjal \& Doige, 1990) are mostly used in those cases. According to ASTM E2611-17 standard (includes the measurement procedures of the two-load method), transfer matrix elements of test specimen are obtained by measuring two complex pressure response functions $\left(H_{i t}=P_{i} / P_{t}, i\right.$ and $t$ may equal to1,2,3,4) at either side of considered structures as shown in Figure 3 for each load. In the measurements, the tube must be ended with any two of hard end, soft end, anechoic end or a sound absorber material. Transfer matrix elements may be calculated by determining sound pressures and particle velocities of test specimen at the inlet and outlet for each load as follows:

$$
\begin{aligned}
& p_{0}=A+B, \\
& p_{d}=C e^{-j k d}+D e^{j k d}, \\
& u_{0}=(A-B) / \rho c, \\
& u_{d}=\left(C e^{-j k d}-D e^{j k d}\right) / \rho c .
\end{aligned}
$$

Here, $d$ is the thickness of test specimen, $\rho$ is the density of air, $c$ is the speed of sound, $k$ is wavenumber, $j=\sqrt{-1}$ and $A, B, C$ and $D$ are forward and backward travelling waves on either side of test specimen and can be calculated by using complex sound pressure response functions:

$$
\begin{aligned}
& A=j \frac{H_{13} e^{-j k l_{1}}-H_{23} e^{-j k\left(l_{1}+s_{1}\right)}}{2 \sin \left(k s_{1}\right)}, \\
& B=j \frac{H_{23} e^{j k\left(l_{1}+s_{1}\right)}-H_{13} e^{j k l_{1}}}{2 \sin \left(k s_{1}\right)}, \\
& C=j \frac{H_{33} e^{j k\left(l_{2}+s_{2}\right)}-H_{43} e^{j k l_{2}}}{2 \sin \left(k s_{2}\right)},
\end{aligned}
$$




$$
D=j \frac{H_{43} e^{-j k l_{2}}-H_{33} e^{-j k\left(l_{2}+s_{2}\right)}}{2 \sin \left(k s_{2}\right)},
$$

where $l_{1}$ and $l_{2}$ are distances of $2^{\text {nd }}$ and $3^{\text {rd }}$ microphones to the inlet of specimen, $s_{1}$ and $s_{2}$ are distance between microphones. One can determine transfer matrix elements by using Eqs. (2)-(5) as follows:

$$
\begin{gathered}
T_{(1,1)}=\frac{p_{0 a} u_{d b}-p_{0 b} u_{d a}}{p_{d a} u_{d b}-p_{d b} u_{d a}}, \\
T_{(1,2)}=\frac{p_{0 b} p_{d a}-p_{0 a} p_{d b}}{p_{d a} u_{d b}-p_{d b} u_{d a}}, \\
T_{(2,1)}=\frac{u_{0 a} u_{d b}-u_{0 b} u_{d a}}{p_{d a} u_{d b}-p_{d b} u_{d a}},
\end{gathered}
$$

$$
T_{(2,2)}=\frac{p_{d a} u_{0 b}-p_{d b} u_{0 a}}{p_{d a} u_{d b}-p_{d b} u_{d a}},
$$

Note that, subscript $a$ and $b$ represent the measurements for the first and the second loads, respectively. Transmission coefficient and transmission loss are calculated by,

$$
\begin{aligned}
& t=\frac{2 e^{j k d}}{T_{(1,1)}+\frac{T_{(1,2)}}{\rho c}+\rho c T_{(2,1)}+T_{(2,2)}}, \\
& T L=20 \log _{10}\left|\frac{1}{t}\right|,
\end{aligned}
$$

respectively. Here, $t$ is sound transmission coefficient and $T L$ is sound transmission loss.

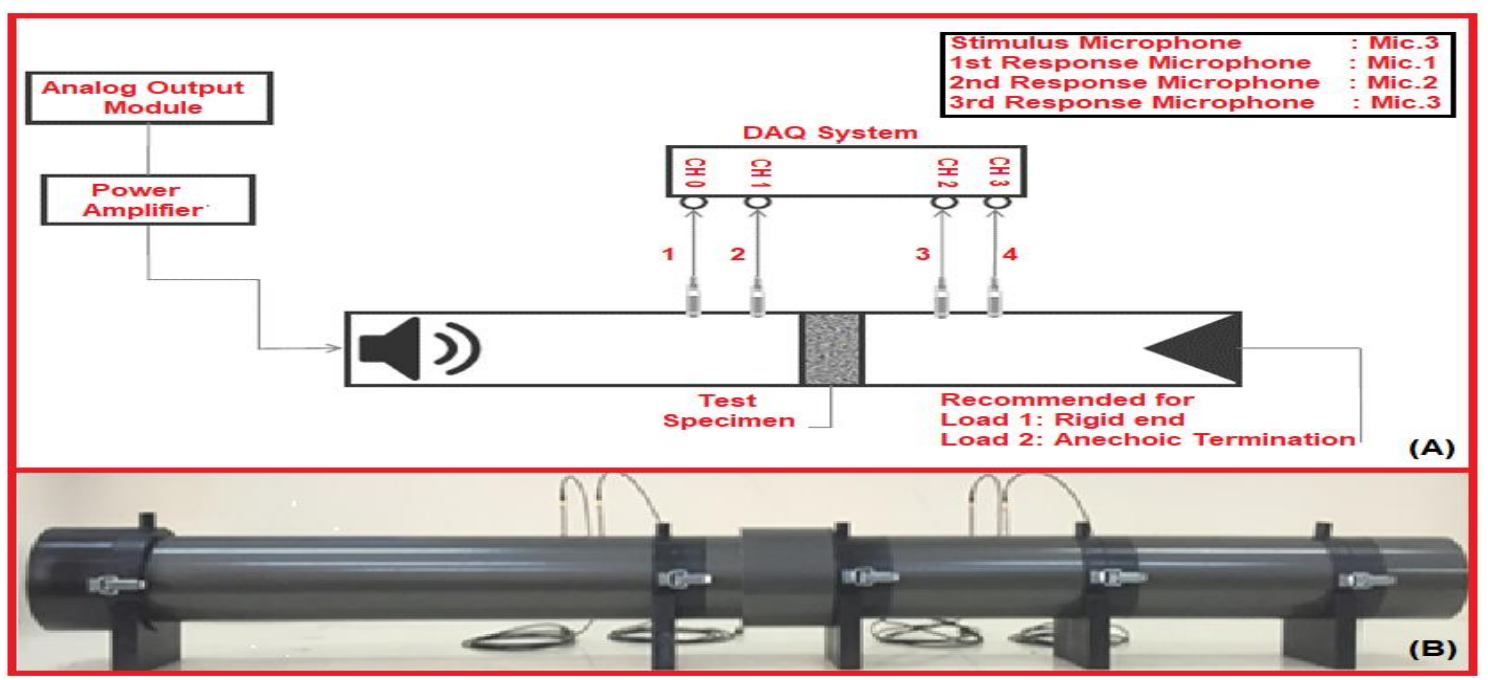

Figure 3. a) Schematic experimental setup, b) impedance tube used in experiments

\section{Results and Discussion}

In this study, transmission losses (TLs) of selected wood species with the same thickness $(8 \mathrm{~mm})$ were measured between $100-1000 \mathrm{~Hz}$ in the impedance tube. In this regard, three samples of each species are measured.
Measured TLs are related with the densities of the species. To relate the density and TL, firstly densities of wood specimens were determined. The average, maximum, minimum and standard deviations of air-dry densities of the test specimens are given in Table 1.

Table 1 . Air dry density

\begin{tabular}{lccccc}
\hline Wood Specimens & $\mathrm{N}$ & Min. & Max. & $\overline{\mathrm{x}}\left(\mathrm{gr} / \mathrm{cm}^{3}\right)$ & $\sigma$ \\
\hline Canadian poplar (Populus x euramaricana) & 30 & 0.295 & 0.340 & 0.332 & 0.015 \\
\hline Black poplar (Populus nigra) & 30 & 0.379 & 0.409 & 0.395 & 0.070 \\
\hline Eucalyptus G. (Eucalyptus grandis), & 30 & 0.491 & 0.555 & 0.520 & 0.066 \\
\hline Beech (Betula pendula) & 30 & 0.502 & 0.568 & 0.529 & 0.051 \\
\hline
\end{tabular}


Table 1. (Continued)

\begin{tabular}{lccccc}
\hline Wood Specimens & $\mathrm{N}$ & Min. & Max. & $\overline{\mathrm{x}}\left(\mathrm{gr} / \mathrm{cm}^{3}\right)$ & $\sigma$ \\
\hline Black pine (Pinus nigra) & 30 & 0.495 & 0.559 & 0.538 & 0.024 \\
\hline Turkish red pine (Pinus brutia Ten,) & 30 & 0.539 & 0.581 & 0.560 & 0.071 \\
\hline Scotch pine (Pinus sylvetris L), & 30 & 0.528 & 0.589 & 0.563 & 0.071 \\
\hline Juniper (Juniperus excelsa) & 30 & 0.552 & 0.599 & 0.587 & 0.020 \\
\hline Cypress (Cupressus sempervirens) & 30 & 0.567 & 0.612 & 0.595 & 0.059 \\
\hline Chestnut (Castanea sativa Mill.) & 30 & 0.589 & 0.623 & 0.610 & 0.023 \\
\hline Plane (Platanus orientalis L.) & 30 & 0.598 & 0.640 & 0.627 & 0.057 \\
\hline Eucalyptus C. (E, camaldulensis Dehnh,) & 30 & 0.647 & 0.698 & 0.649 & 0.084 \\
\hline Oriental beech (Fagus orientalis Lipsky,) & 30 & 0.649 & 0.678 & 0.652 & 0.024 \\
\hline White Oak (Quercus alba) & 30 & 0.657 & 0.711 & 0.691 & 0.040 \\
\hline Ash (Fraxinus excelsior) & 30 & 0.694 & 0.724 & 0.709 & 0.084 \\
\hline Acacia (Robinia pseudoacacia L.) & 30 & 0.685 & 0.743 & 0.731 & 0.051 \\
\hline N: Number of test specimens, $\bar{x}:$ Average, $\sigma:$ Standard deviation, Min: Minimum, Max: Maximum, * wood species \\
were listed to their density, from low to high.
\end{tabular}

Sound transmission loss of the wood species for the samples with the diameter of $\varnothing 99 \mathrm{~mm}$ between $100-1000 \mathrm{~Hz}$ and transmission loss were measured by using two-load method. 1/3 octave band averaged results are presented in Figure 4 and Table 2.

According to Table 2 and Figure 4, there are some woods species those present higher TLs than expected in accordance to density, i.e, TLs of Black poplar (having the density of $0.395 \mathrm{gr} / \mathrm{cm}^{3}$ ) is higher than the TLs of Acacia $\left(0.731 \mathrm{gr} / \mathrm{cm}^{3}\right)$, White Oak $\left(0.691 \mathrm{gr} / \mathrm{cm}^{3}\right)$ and Oriental beech $(0.652$ $\mathrm{gr} / \mathrm{cm}^{3}$ ) in $1000 \mathrm{~Hz}$. This may be due to fact that, there are several factors (the anisotropy and orthotropy of wood, mechanical properties (modulus of elasticity, hardness and stiffness), chemical composition of wood, anatomical differentiation such as annual ring width, latewood ratio, ray cells, resin canals, etc., the air contained in the cavities of wood cell and porous structure of wood) which affect TL in wood material (Watanabe et al., 1967; Bucur, 2006; Fukuta et al., 2012). Besides, TL increases when the wood structure irregular and the specific mass, the roughness of the surface, the moisture content and heat increase. In one study, it has been reported that low density material specimens give better results (higher TL) than high density material specimens depending on the density values of wood and wood based materials (Godshall \& Davis, 1969). For the species those have lower TLs, traditional methods for improving sound insulation performance (such as increasing the surface density and thickness of the considered material) may be used to increase TL. However, this method is neither economic nor convenient in terms of the processing and utilization of materials (Li et al., 2010).

Considering TL results of wood species high averaged transmission loss is observed for Ash, Oriental beech, Plane and Turkish Red Pine species whereas Juniper, Eucalyptus and White Oak species have lower averaged transmission loss. In the measurements, stiffness controlled region and the first resonance frequency are clearly observed in Figure 4. Except Ash, Chestnut and Black Pine species, the first natural frequency of the species is observed between $250-400 \mathrm{~Hz}$ for all species. As it is known, the natural frequency is calculated by square root of ratio of stiffness and mass. Since the volumes of all considered species are identical, Ash, Chestnut and Black Pine may have higher ratio of stiffness and density than the others. 

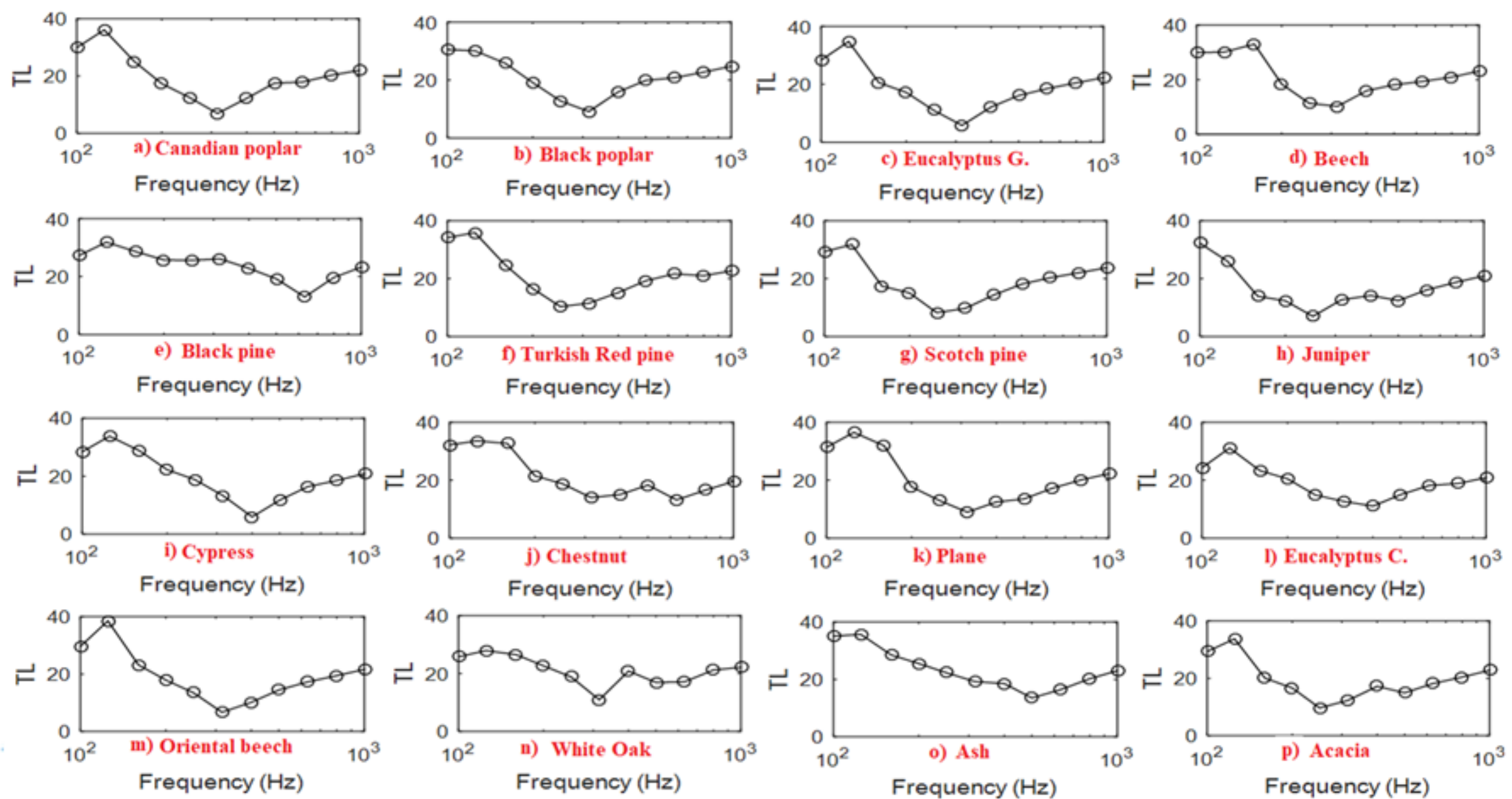

Figure 4. Sound transmission loss of a) Canadian poplar (Populus x euramaricana), b) Black poplar (Populus nigra), c) Eucalyptus G. (Eucalyptus grandis), d) Beech (Betula pendula), e) Black pine (Pinus nigra), f) Turkish Red pine (Pinus brutia Ten,), g) Scotch pine (Pinus sylvetris L), h) Juniper (Juniperus excelsa), i) Cypress (Cupressus sempervirens), j) Chestnut (Castanea sativa Mill.), k) Plane (Platanus orientalis L.), 1) Eucalyptus C. (E, camaldulensis Dehnh,, $\mathrm{m}$ ) Oriental beech (Fagus orientalis Lips,) n) White Oak (Quercus alba), o)Ash (Fraxinus excelsior), p), Acacia (Robinia pseudoacacia $L$.). * wood species were listed to their density, from low to high. 
Table 2. 1/3 octave band averaged sound transmission loss of different wood species with the same thickness* Sound Transmission Loss (dB)

\begin{tabular}{|c|c|c|c|c|c|c|c|c|c|c|c|c|c|c|c|c|}
\hline & & & & & & & Soun & $\mathrm{cancm}$ & ion Los & dB) & & & & & & \\
\hline 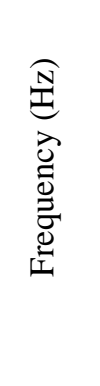 & 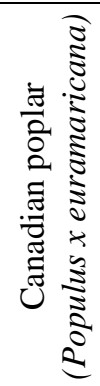 & 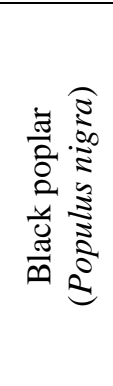 & 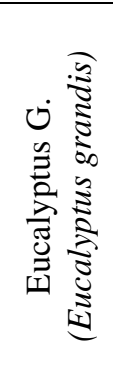 & 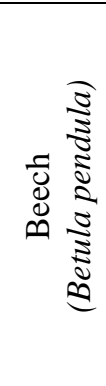 & 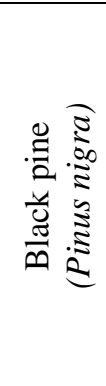 & 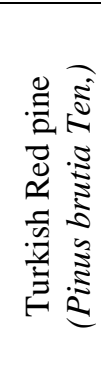 & 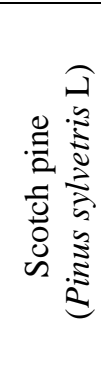 & 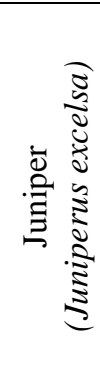 & 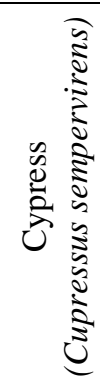 & 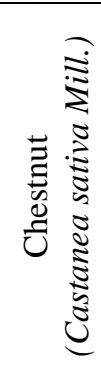 & 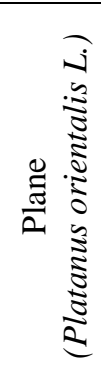 & 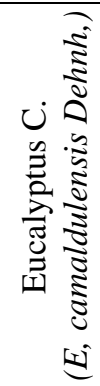 & 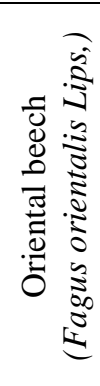 & 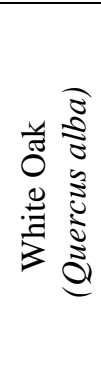 & 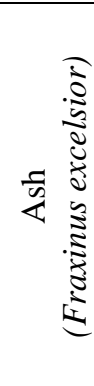 & 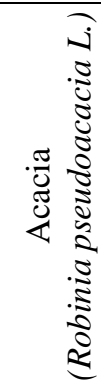 \\
\hline 100 & 29.96 & 30.58 & 28.41 & 29.97 & 27.26 & 34.14 & 29.28 & 32.21 & 28.42 & 32.17 & 31.36 & 24.29 & 29.66 & 25.80 & 35.11 & 29.37 \\
\hline 125 & 36.12 & 30.14 & 34.80 & 30.13 & 31.89 & 35.86 & 31.74 & 26.01 & 33.77 & 33.56 & 36.50 & 31.11 & 38.56 & 27.94 & 35.70 & 33.76 \\
\hline 160 & 25.03 & 25.82 & 20.60 & 33.05 & 28.54 & 24.69 & 17.35 & 13.86 & 28.68 & 32.67 & 31.87 & 23.29 & 23.22 & 26.53 & 28.53 & 20.10 \\
\hline 200 & 17.33 & 19.12 & 17.22 & 18.41 & 25.74 & 16.51 & 15.03 & 12.31 & 22.18 & 21.49 & 17.71 & 20.49 & 17.90 & 22.67 & 25.53 & 16.63 \\
\hline 250 & 12.53 & 12.82 & 11.04 & 11.39 & 25.63 & 10.32 & 8.22 & 6.96 & 18.85 & 18.80 & 13.10 & 14.95 & 13.49 & 18.88 & 22.33 & 9.65 \\
\hline 315 & 6.93 & 9.14 & 5.82 & 10.23 & 26.13 & 11.48 & 9.68 & 12.66 & 13.32 & 14.02 & 9.01 & 12.72 & 6.68 & 10.97 & 19.26 & 12.30 \\
\hline 400 & 12.24 & 15.94 & 12.19 & 15.97 & 22.83 & 15.15 & 14.42 & 14.14 & 5.96 & 15.09 & 12.52 & 11.10 & 10.15 & 20.87 & 18.55 & 17.23 \\
\hline 500 & 17.48 & 19.89 & 16.12 & 18.13 & 19.21 & 19.23 & 18.07 & 12.38 & 11.71 & 18.33 & 13.55 & 15.01 & 14.45 & 16.96 & 13.54 & 14.95 \\
\hline 630 & 17.90 & 20.81 & 18.51 & 19.36 & 12.98 & 21.62 & 20.26 & 16.09 & 16.41 & 13.22 & 17.24 & 18.18 & 17.26 & 17.17 & 16.41 & 18.18 \\
\hline 800 & 20.31 & 22.76 & 20.53 & 20.93 & 19.72 & 20.98 & 22.03 & 18.73 & 18.52 & 16.64 & 20.15 & 18.88 & 19.47 & 21.25 & 20.25 & 20.46 \\
\hline 1000 & 21.97 & 24.81 & 22.33 & 23.14 & 23.28 & 22.64 & 23.72 & 20.92 & 20.86 & 19.56 & 22.25 & 20.90 & 21.65 & 22.18 & 23.06 & 22.80 \\
\hline verage & 27.28 & 24.92 & 25.93 & 26.27 & 26.16 & 28.27 & 24.41 & 23.41 & 25.96 & 27.56 & 28.52 & 23.10 & 28.99 & 23.11 & 29.00 & 25.46 \\
\hline
\end{tabular}

Note that, high TLs among the species are written by bold letters in Table 2. * wood species were listed to their density, from low to high. 
Behaviour of the mass law region (TL gains $6 \mathrm{~dB}$ with frequency per octave) is evaluated for the considered species except Black pine, Cypress, Chestnut, Ash and Acacia. However, increment occurs between 4.5-7 dB instead of $6 \mathrm{~dB}$ for different species. This may be due to experimental errors or averaging the results in $1 / 3$ octave bands. For the species in which mass law region are not observed, measurements must be performed up to higher frequencies than $1000 \mathrm{~Hz}$. Since Black pine has high TLs in lower frequencies, this species may be a good alternative insulation material for lower frequency noise. A similar relation was reported by some researcher for several kinds of wood and wood based panels reported in literature (Davern, 1977; Kang et al., 2006; Kang et al., 2010; Chang \& Zhihui, 2011; Smardzewsk et al., 2014). The acoustic properties of individual wood species can be very different (Chauan et al., 2005; Mohebby et al., 2007).

As the frequency increases, high TL is observed for the species with lower densities. For example, at higher frequency $(1000 \mathrm{~Hz})$, black poplar wood specimens with lower density have higher value than the Ash wood species. No relation between averaged transmission loss and density is observed.

\section{Conclusion}

Wood species are used quite frequently in building and decoration. Although there are quite a few studies on the mechanical performance of wood species in the literature, studies on their acoustic performances are very limited. In this study, sound transmission losses (TLs) of 16 different wood species having the same thickness were measured in impedance tubes between $100-1000 \mathrm{~Hz}$ to compare the insulation performances of the species. In addition, the densities of the tested species were determined experimentally. Although no relation can be established between the average TLs and the density of the species, the higher transmission loss has been obtained for the lower density materials with increasing frequency. According to the results, Ash, Oriental beech, Plane and Turkish Red Pine species for the entire frequency band and Black Pine for the low frequency noise problems, which are mostly problematic in insulation; problems will be good alternative materials among other wood species. It is thought that the results of this research can be a guide in the selection of right wood species. By this guide, wood material can use effectively and correctly in applications where acoustic properties are important.

\section{Acknowledgements}

The authors thank to Prof. Dr. Abdullah SEÇGIN for allowing the use of the impedance tube kit at Dokuz Eylül University.

\section{References}

ASTM Standard E1050-12. (2012). Standard test method for impedance and absorption of acoustical materials using a tube, two microphones and a digital frequency analysis system, ASTM International : West Conshohocken, PA, USA,

ASTM E2611-17. (2017). Standard Test Method for Normal Incidence Determination of Porous Material Acoustical Properties Based on the Transfer Matrix Method 1 ; ASTM International : West Conshohocken, PA, USA,

ASTM C423-09. (2009). Standard Test Method for Sound Absorption and Sound Absorption Coefficients by the Reverberation Room Method, ASTM International : West Conshohocken, PA, USA,

ASTM E2249-19. (2003). Standard Test Method for Laboratory Measurement of Airborne Transmission Loss of Building Partitions and Elements Using Sound Intensity, ASTM International: West Conshohocken, PA, USA,

Bal, B. C. \& Bektaş, İ. (2018). Odunun yoğunluğu ile mekanik özellikleri arasındaki ilişkinin belirlenmesi üzerine bir araştırma. Mobilya ve Ahşap Malzeme Araştırmaları Dergisi, 1(2), 51-6.

Berkel, A., (1970). Ağaç malzeme teknolojisi, İstanbul üniversitesi, Orman fakültesi yayınları, İstanbul.

Bies, D. A. \& Hansen, C. H. (2009). Engineering noise control: Theory and practice, fourth edition. In Engineering Noise Control: Theory and Practice, (4th ed.). Spon Press/Taylor \& Francis.

Bucur, V. (2006). Acoustics of wood, 2nd ed. Springer Series in Wood Science, Springer, Berlin, Heidelberg, Germany.

Chauan, S., Entwistle, K.M. \& Walker, J.C.F. (2005). Differences in acoustic velocity by 
resonance and transit-time methods in an anisotropic laminated wood medium. Holzforschung, 59,428-434.

Chang, L., W. U. \& Zhihui, W.U. (2011). Study on sound absorption performance of extruded tubular particleboard used in indoor wooden products, Journal of Nanjing Forestry University, 35(2), 56-60.

Crocker, M. J. (2007). Handbook of noise and vibration control. New Jersey, John Wiley.

Çavuş, V. (2019). Mühendislik Ürünü Ağaç Malzemelerde Yükselen Trend ; Çapraz Tabakalanmış Kereste. Bartın Orman Fakültesi Dergisi, 21 (2), 560-569.

Davern, W. A. (1977). Perforated facings backed with porous materials as sound absorbers an experimental study. Applied Acoustics, 10, 85-122.

Fukuta, S., Nishizawa, M. \& Takasu, Y. (2012). Sound absorption and form retention of newly developed heat-insulating/acoustic material. Eur. J. Wood Prod. 70, 697-704 https://doi.org/10.1007/s00107-012-0607-x

Godshall, D. \& Davis, J.H. (1969). Acoustical Absorption Properties of Wood-Base Panel Materials. Research Paper FPL 104. USDA, Forest Service, Forest Products Laboratory USA.

Kang, C., Matsumura, J. \& Oda, K. (2006). A comparison of the standing wave and two microphone methods in measuring the sound absorption coefficient of wood. J. Fac. Agr. Kyushu Univ., 51 (1), 1-4.

Kang, C.W., Kim, G.-C., Park, H. J., Lee, N.-H., Kang, W., \& Matsumura, J. (2010). Changes in permeability and sound absorption capability of yellow poplar wood by steam explosion treatment. Kyushu University Journal of the Faculty of Agriculture, 55(2), 327-332.

Li, X., Liang, S., Wu, N. J. \& Chang, Y.Y. (2010). Experimental study on sound insulation characteristics of embedded cocured composite damping structures. Noise and Vibration Control, 10(5), 91-94.

Lung, T.Y. \& Doige, A.G. (1983). A time averaging transient testing method for acoustic properties of piping systems and mufflers with flow. J. Acoust. Soc. Am. 73, 867-876. doi:10.1121/1.389056.

Mohebby, B., Yaghoubi, K. \& Roohnia, M. (2007). Acoustic properties of hydrothermally modified mulberry (Morus alba L.) wood. The Third European Conference on Wood Modification, Eds. Hill, C.A.S., Jones, D., Militz, H., Ormondroyd, G.A.The Angel Hotel, Cardiff, UK, 15-16 October 2007.
Munjal, M.L. \& Doige, A.G., (1990). Theory of a two source-location method for direct experimental evaluation of the four-pole parameters of an aeroacoustic element. $J$. Sound Vib., 141,323-333. doi:10.1016/0022460X(90)90843-O.

Selmani, M. \& Sönmez, A. (2017). İç Dekorasyonda Kullanılan Sapsız Meşe (Quercus Petraea L.) ve Sarıçam (Pınus Sylvestrıs L.) Ağaçlarında Kesiş Yönü Ve Su Bazlı Vernik Türünün Ses Geçiş Kaybına Etkisi. Illeri Teknoloji Bilimleri Dergisi, 6 (3), 338-344.

Smardzewski, J., Batko, W., Kamisi ń ski, T., Flach, A., Pilch, A., Dziurka, D., Mirski, R., Roszyk, E., Majewski, A. (2014) Experimental study of wood acoustic absorption characteristics. Holzforschung 68:467 - 476.

Sirel, Ş., 2000. Yapı Akustiğinde 30 Terim 30 Tanım. Yapı Fiziği Uzmanlık Enstitüsü, 9, İstanbul.

TS 2470, (1976). Odunda Fiziksel ve Mekaniksel Deneyler İçin Numune Alma Metodları ve Genel Özellikler, T.S.E., Ankara 2-4

TS 2472, (1976). Odunda, fiziksel ve mekaniksel deneyler için birim hacim ağırlığg tayini, Türk Standartları Enstitüsü, Ankara.

Voichita, B. (1995). The Acoustics of Wood, 1st edition, Boca Raton, CRC Press, 300 Pages, https://doi.org/10.1201/978020371012

Watanabe, H., Matsumoto, T., Kinoshita, N. \& Hayashi, H. (1967) Acoustical study of woods and wood products. I. On the normal absorption coefficient of wood. Mokuzai Gakkaishi, 13(5), 117-182. 